\title{
Current Challenges Facing Chinese Financial Supervision and Methods of Handling these Challenges*
}

\author{
Bence Varga
}

This paper presents the main challenges currently facing China's financial supervisory authority and the supervisory response to these challenges, focusing on the shadow banking system and Digital Finance. The author seeks to find out what reforms were introduced and what tools were applied in the realm of supervision in the recent period, what results they have yielded and whether any further reform is necessary to improve the efficiency of Chinese financial supervision, and if so, in what area(s). This paper focuses on the activities and toolset of the CBRC, the main financial supervisory body, and also covers the relevant tasks discharged by the PBC.

Journal of Economic Literature (JEL) codes: G18, G21, G28

Keywords: financial supervision, CBRC, financial institutions, shadow banking system, Digital Finance

\section{Introduction}

In parallel with the modernisation of the Chinese banking system (including the establishment of a two-tier banking system, the creation of a securities market and the adoption of the law regulating the operation of commercial banks) which began in 1978, the supervisory body and supervisory methodology has also undergone transformation. That said, it was the China Banking Regulatory Commission (CBRC), established in 2003, governed by the State Council, and tasked primarily with supervising financial institutions ${ }^{1}$ which brought about the greatest change in regulatory terms. With its establishment, the People's Bank of China (PBC) transferred the majority of the supervisory tasks it had previously performed to the CBRC. The CBRC's core task is to authorise the establishment, termination and business scope of banking institutions, conduct on-site examination and off-site supervision, draft supervisory guidelines and regulations and take enforcement action against infringements. Further tasks include conducting fit-and-proper

* The views expressed in this paper are those of the author(s) and do not necessarily reflect the offical view of the Magyar Nemzeti Bank.

Bence Varga is a senior supervisor of the Magyar Nemzeti Bank's Credit Institutions Supervision Directorate. E-mail:vargabe@mnb.hu.

The manuscript was received on 16 September 2016.

${ }^{1}$ In the context of this paper, "financial institution" mainly refers to banks, and does not include insurance companies and investment firms. 
assessment of senior managerial personnel, carrying out consumer protection functions, compiling and publishing statistics and reports on the banking industry as a whole in accordance with relevant regulations, and making proposals on the resolution of problem deposit-taking institutions, in consultation with other regulatory authorities. In addition, it is responsible for the administration of the supervisory boards of the major state-owned banking institutions and other functions delegated by the State Council (CBRC 2016).

The PBC also has significant powers in respect of the entire banking system, along with its microprudential supervisory function applying to individual institutions. Its scope of responsibilities includes preventing and reducing the emergence of systemic risk and maintaining financial system stability (PBC 2016), while also performing the oversight of the payment and settlement system. In addition to traditional central bank functions, it also regulates interbank lending, foreign currency trading, foreign currency exchange and certain financial oversight tasks (SEACEN 2013), such as those related to the regulation of the amount of transactions per account in the case of Digital Finance products. China's supervisory framework features what is referred to as a "one bank and three committees" structure, which refers to the separation of central bank and supervisory functions, but nevertheless, similarly to the supervisory practice prevailing in the EU (MNB 2013), it can be classified among countries where the central bank also holds a certain supervisory mandate. Among the EU member states, this group includes Austria and Germany, although all the PBC's supervision-related tasks are far more limited than in these countries or in countries featuring a Twin Peaks style system (such as the Netherlands or Belgium). The China Securities Regulatory Commission (CSRC), which in charge of capital market supervision, and the China Insurance Regulatory Commission (CIRC), which in charge of insurance institution supervision, also perform supervisory functions alongside the CBRC and the PBC.

Besides changes in the supervisory body, the applied methodology also underwent a transformation, with principle-based regulation gaining momentum following the turn of the millennium alongside the earlier, essentially rule-based regulation that typically prevailed at the end of the 20th century (the Basel accords also require the former approach), which has given rise to a mixed supervision model. Rule-based regulation can be applied more easily, supervisory monitoring can be conducted relatively simply and it affords flexibility for ad hoc interventions, however there is a greater risk of loopholes with the emergence of financial innovation. Meanwhile, principle-based regulation affords greater leeway for creating implementation methods, but may require more in-depth interpretation and a greater number of guidelines. An example of rule-based regulation is the credit quota applied earlier to avoid procyclicality (Loechel et al. 2010), while an example of principle-based regulation is the restriction of the domestic activities of foreign financial institutions 
using offshore derivative products for marketing purposes (He 2014). The fact that the Financial Stability Board (FSB) report published in November 2015 on global systemically important banks (G-SIBs) identifies four major Chinese banks (Agricultural Bank of China, Bank of China, China Construction Bank, Industrial and Commercial Bank of China) increases the significance of China's financial supervision (FSB 2015).

The following section presents the main challenges faced by Chinese supervision in the late 1990s and currently - highlighting, in the latter case, the shadow banking system and Digital Finance - alongside the supervisory regulatory framework. This paper attempts to provide help for understanding the operating background and unique characteristics of the Chinese financial institutions present in Hungary, and to contribute to an adequate and effective regulatory approach to phenomena that also carry risk for Hungary.

\section{The main challenges facing financial supervision, their changes and handling methods}

Chinese financial market supervision has faced numerous challenges recently, which are also linked to the reforms introduced. These include the introduction of deposit insurance, the comprehensive formal liberalisation of interest rates, the introduction of the PBC's Macro Prudential Assessment (MPA), the launch of pilot programmes linked to securitisation, the introduction of equal capital requirements and risk weights for certain on- and off-balance sheet activities, and the application of a "periodic average" for the monitoring of financial institutions' reserve requirements (IMF 2016). Besides the foregoing, Chinese supervision will also face challenges from the Basel IV reforms drafted by the Basel Committee and the introduction of TLAC (Total Loss Absorbing Capacity).

\subsection{Challenges and their handling methods in the late 1990s}

The nature of the challenges facing Chinese supervision and consequently, the methods of handling such challenges differed. At the turn of the millennium, supervision faced the following challenges: during the transition from a planned economy to a market economy, financial institutions failed to fully adapt their activities to the new market circumstances, which made it difficult for the CBRC to supervise these institutions which lacked adequate risk awareness. A sign of the relative weakness of supervision in the past is that the PBC only qualified as an exclusively central bank organisation after 1984; prior to that, its operations included collecting deposits and lending, and supervisory bodies were only created after this point in time, so neither the central bank nor the supervisory bodies and related regulations boast a long history. The public disclosure (and recognition of the importance) of relevant information on financial institutions was not fully 
achieved during this period, and the exit of financial institutions from the market was also contentious (Esheng 1999). The volume of non-performing loans was also an issue: it was estimated at around $20-50 \%$ of loans, thus exceeding banks' capital stock (Komlóssy et al. 2015). The majority of these issues were resolved over the past two decades, as the risk awareness and experience of the supervisory bodies have increased, the supervisory toolset has grown, the majority of non-performing loans have been temporarily resolved through asset managers, bank recapitalization has been completed in multiple steps, exit strategies have been developed, and the range of publicly disclosed information has increased. In the context of what is referred to as paternalistic regulation, the CBRC shared the practices that it deemed the best with the supervised institutions in an effort to increase risk awareness, the application of which was definitely helpful to domestic banks, despite the fact that diverging parent bank practices created difficulties for foreign banks in several cases (He 2012).

The fact that the Basel Committee found China's capital regulation system adequate and consistent with Basel principles in 2013 (BIS 2013), that the CBRC has made the public disclosure of relevant information a priority (He 2012) and that the European Commission qualified China's supervisory and regulatory system as being equivalent to the European Union's relevant system (EC 2014) shows that the challenges facing supervision are being addressed. An example of the CBRC's expanded supervisory toolset was the restriction of the loan-to-deposit ratio of domestic and foreign banks, which was capped at $75 \%{ }^{2}$ and was valid until 1 October 2015. Given that the majority of Chinese banks were credit-focused, this indicator was initially an effective tool for controlling outstanding borrowing, but became obsolete as other fundraising options, such as interbank lending, bond issuance and repos became widespread. Customer funds were placed in asset manager products, shares and private capital rather than bank deposits, which caused banks to engage in window-dressing to inflate their reported deposit numbers, and thus the use of other, more sophisticated indicators (such as LCR and NSFR) proved to be more effective (Zhang 2015). In terms of the loan-to-deposit ratio, the CBRC granted a three-year transitional period to foreign banks, but it was more difficult to meet this requirement, as foreign banks have more limited deposit collection options compared to their domestic peers (PWC 2010).

The strength of the supervision applied to foreign bank's operations is illustrated by the fact that all bank products and services are subject to licensing, not only specific activities, but all products and services linked to the core activity (including, for instance, bank card services). ${ }^{3}$ The CBRC identified seven circumstances for the

\footnotetext{
${ }^{2}$ Law of the People's Republic of China on Commercial Banks (2003), Article 39, Section (2).

${ }^{3}$ Decree of China Banking Regulatory Commission (2006): Based on "Rules for Implementing the Regulations of the People's Republic of China on Administration of Foreign-funded Banks" (He 2014).
} 
fit-and-proper assessment. If any of these circumstances apply - for instance, if the person in a management position failed to attend one third of board meetings during a business year, did not submit any comments or did not require the correction of the financial institutions business strategy or risk management policy following the identification of shortcomings - the person will be deemed professionally unfit. The CBRC defined an additional four circumstances, and if any of them apply, then the person in a management position will be deemed professionally unfit: public disclosure of trade secrets violating the legitimate rights of the financial institution; gaining unlawful personal benefits or advantages through abuse of office; failure to issue a counter opinion when the financial institution suffers material loss stemming from the adoption of a board decision that violates the law, relevant regulations or internal regulations; or any other circumstance that the supervisory authority identifies as a severe breach of obligations. ${ }^{4}$ The requirement for persons to show up in person at the financial institution and the recording of the contract conclusion process (on videotape) by financial institutions represents a great step forward in terms of customer identification. However, this requirement affected foreign institutions adversely, because many did not have the expansive branch network of their domestic peers (PWC 2010), which offered "protection" for domestic financial institutions, which are typically vulnerable within the competition represented by foreign financial institutions; at the same time, the benefits of more intense competition cannot be ignored (such as new practices, higher standard products and services, etc.) (He 2012, Achhorner et al. 2006). The current uncertainty surrounding the reliability of certain national economic data (such as the unemployment rate) clearly affecting risk strategies and business plans creates difficulty for both foreign and domestic financial institutions (Bloomberg 2016).

\subsection{Main challenges and their current handling methods}

\subsubsection{The shadow banking system}

Currently, one of the major financial supervisory challenges for China is the shadow banking system, which has gradually and increasingly gained significance since 2008. This financing system operating alongside the banking system plays a pivotal role in the Chinese economy. In late 2014, the ratio of assets forwarded through the shadow banking system reached $8 \%$ of total assets (Lasak 2015). The characteristics of China's shadow banking system differ from those found in Western countries in many regards. Specifically, China's shadow banking system mainly affects the domestic financial system, is mainly driven by commercial banks, features an underdeveloped secondary market, and the shadow banking system comprises less complex financial instruments, most of them initiated by individuals, whereas

\footnotetext{
${ }^{4}$ Decree of China Banking Regulatory Commission (2010): “Guidance on the Directors' Performance Appraisal of Commercial Banks", Article 31-32.
} 
Western type shadow banking systems that typically affect both the domestic and foreign financial system, is mainly driven by non-bank financial institutions, the secondary market is relatively well developed and transactions are mainly conducted by institutional investors (Linden 2015). The willingness to seek out alternative forms of financing has also been driven by the funding shortages affecting certain sectors and industries and the generally low interest rate levels. The two main "products" of the Chinese shadow banking system are WMPs (Wealth Management Products) and TPs (Trust Products); the former are mainly issued through financial intermediaries, which are not licensed to collect deposits or engage in lending, but are authorised to manage such activities. These products are more similar to loans based on their characteristics, but there are some that are very speculative in nature. Trust Products are mainly offered by non-bank financial institutions, such as trust companies, brokers, and insurance companies, in partnership with banks. WMPs and TPs accounted for more than 50\% of China's GDP in 2015.

Drafting regulations on the shadow banking system has been a priority for China's government recently, in the context of the 12th five-year (2011-2015) plan. The main issues and the related regulatory framework were defined in a circular letter aimed at bolstering the regulation of the shadow banking system. A need to specify the allocation of responsibility among the various supervisory bodies was laid down, as the current supervisory system applies a sectoral approach, under which different supervisory bodies perform the supervision of different sectors, as a result of which the "supervision" of the shadow banking system is shared among several institutional bodies, which raises questions of responsibility that have not yet been resolved. In this regard, an integrated or Twin Peaks type supervisory model could offer a solution, but no meaningful steps have been taken in this direction. In addition, increasing transparency is also priority, as the shadow banking system, due to its nature, decreases the transparency of capital flows and financial institutions, which in turn lowers the effectiveness of macroprudential regulation. It is therefore paramount to improve the transparency of the statistics and information policy on the shadow banking system. In this regard, there have been some initiatives, for instance for banks to manage separate accounts for all WMPs, along with the associated supportive and information documents with adequate content. Thirdly, the regulation of the affected institutions and products is a priority, and in this context, based on the CBRC's measure, commercial banks are required to restrict their WMP exposure; while this measure only restricts the shadow banking system without eradicating it (Linden 2015), it nevertheless deserves special attention.

The measures introduced to address the shadow banking system have spurred the appearance of newer and newer shadow banking system products. In 2008, WMPs were the greatest challenge for the CBRC in terms of managing the shadow banking system. The CBRC adopted numerous supervisory measures to fight 
these products, mainly in the form of authority notices that took advantage of the supervisory framework's flexibility. In these notices, the CBRC stipulated that the ratio of non-traditional assets to the WM portfolio could not exceed $30 \%$, and the proportion of the WM portfolio within the balance sheet total could not exceed $4 \%$, and requirements for disclosing the data of such products were also defined. At the same time, 2009 saw a further increase in WMPs, which necessitated the issuance of additional notices. In two notices issued in 2009 , the CBRC regulated the reporting system of WM services and rolled out tighter rules for managing investment funds, but these regulatory documents failed to duly address the links within the risks inherent to WM services, and the frequent notices created uncertainty among capital market players. The aforementioned measures significantly slowed the spread of WMPs, but gave rise to a new shadow banking system activity through WM cooperation between banks and trust companies in 2010 in a bid to circumvent the relevant rules, referred to as trust-based lending, which affects banks' off-balance sheet items (Hu et al. 2016). In response to this, the CBRC issued new notices in 2010 and 2011 to reinforce the regulation of WM cooperation between banks and trust companies, in the context of which commercial banks were required to transfer their off-balance sheet assets within a deadline of two years (later amended to one year and four months), which was regularly monitored by the CBRC. If a bank failed to comply, it had to set aside a $10.5 \%$ risk reserve on its exposure of this type. These measures helped decrease banks' hidden off-balance sheet risks and to curb trust-based lending, but 2012 saw the emergence of non-traditional loan intermediation (such as reverse repos) on the Chinese money market with the participation of banks and trust companies, or other third party players. In 2014 the CBRC created a supervisory framework to address these products (Zheng 2015) and issued numerous authority notices (e.g. capping investments in non-traditional credit instruments and crafting related risk management methods).

For the sake of international comparison, in Europe, it was the CRR (Capital Requirements Regulation) that granted the EBA (European Banking Authority) the power to draft a recommendation for restricting banks' exposure to the shadow banking system. According to the EBA's recommendations on the shadow banking system, banks must apply effective processes and control mechanisms, coupled with internal frameworks, individual and aggregate limit systems, and also be able to identify their associated individual exposures and control these risks. However, tightening regulations governing banks is not enough, as this may further push their activities towards the shadow banking sector (Seregdi 2016). So the measures introduced by China's supervision and its capacity to react to the shadow banking system does not fall short of the measures seen in Europe, but there are uncertainties surrounding its degree of success (for instance in terms of its management of maturity mismatch). 
It should be emphasised that most regulatory guidelines and policies in China are introduced after broad public consultation, their communication to the public was frequent and in-depth, which contributed to the effectiveness of the measures. However, the regulation of the shadow banking system still exhibits shortcomings, firstly because the regulation lacks a systemic-level guiding principle that factors in both economic development and risk prevention and regulates the associated financial innovation in such a manner that supports real economic development. The integration of supervisory bodies or better communication between them would increase the harmony between the supervisory tools applied and macroeconomic objectives. Currently, every supervisory body is in charge of supervising the institutions they authorise, but this presents the danger of inadequate assessment of risks stemming from enhanced relationships between institutions and cross-sector products within the shadow banking system. This divided supervisory structure may also contribute to the emergence of disagreements between the various bodies (He 2014). On the other hand, supervisory bodies underestimated financial institutions' capacity to adopt financial innovation, and the time required to do so. This also contributed greatly to the rapid emergence of new financial products in response to the supervisory measures introduced. Thirdly, the assessments following the papers, impact assessments and guidelines preceding the issuance of regulatory guidelines are not sophisticated enough. However, solving these problems would only be sufficient to address the existing issues in the short term; material change would require structural reforms, but first and foremost the creation of a more diversified financial system than the current one, further reduction of systemic and regional risks, tighter regulation of non-traditional lending methods within the banking system and deeper structural reform within the financial system. These can be considered as the most important tasks (Hu et al. 2016).

\subsubsection{Digital Finance}

The marked rise in online financial services (such as Yu'E Bao, Alipay) in China began in 2013, and there were over 2,500 P2P platforms operating by $2015,{ }^{5}$ representing capital in excess of RMB 375 billion. ${ }^{6}$ Initially, the CBRC adopted a lenient approach to supervising these activities in a bid to offer a partial solution to the funding difficulties faced by SMEs. Meanwhile, these were also regarded as a main instrument fostering the broader spread of financial services. The idiosyncrasies of the credit- and price system (including a shortage of market loans, the impact of non-market mechanisms on certain prices, etc.) and more generally, the shortcomings of China's financial system contributed the rising share of Digital Finance products (Hu et al. 2016). The regulation of Digital Finance prior

\footnotetext{
${ }^{5}$ Peer to peer (P2P) platforms are online services supplied by innovative firms in the context of which lending and borrowing takes place with the intermediation of financial institutions and insurance companies, but typically without them.

${ }^{6}$ HUF 15,536.25 billion (based on the MNB exchange rate of CNY/HUF 41.43 valid on 30 September 2016).
} 
to 2015 remained lenient in spite of the fact that many P2P service providers went bankrupt as early as in 2011 due to payment difficulties, and most industry professionals supported regulation of this area (Zhou et al. 2015). As a result of lenient supervision, nearly one third of all P2P platform transactions became nonperforming, or raised the suspicion of misappropriation of the capital involved. As a result of the above, the regulation of online financial services became a priority, and in 2015, the PBC announced its objective to create a regulatory framework for Digital Finance as soon as possible at the 12th National People's Congress. Accordingly, the CBRC issued guidance and draft regulation in 2015, and further regulatory steps are expected in the future. Based on the CBRC's approach to P2P, no capital or licensing requirements would be defined, and the authorisation of platforms would mainly occur in the context of registration. In addition, the range of unauthorised activities would be defined, e.g. transactions between parties within the same circle of interest, the assumption of principal guarantees, the pledging of collateral, etc. The regulatory framework includes the requirement for platforms to distinguish their own funds from foreign funds, placing the latter on a deposit account at a financial institution. The regulation issued by the PBC in 2015 also emphasised the importance of customer identification, and depending on the authentication methods used, payments per account will be limited to RMB 1,000 over the life of the account, RMB 100,000 or RMB 200,000 per year (Jingu 2016). Based on the framework, the fundamental principles governing the regulation of Digital Finance are "tolerate, encourage, guide and standardise" and the associated supervisory requirements can be summed up as "comprehensive, timely, professional and effective".

Hence, significant progress has been made in terms of the regulation of Digital Finance by the Chinese supervisory authorities, but the financial products classified as Digital Finance currently and will continue to create challenges for them, as Digital Finance functions within a mixed operating model that involves multiple sectors, and the decentralised nature of supervisory bodies renders their supervision more difficult. The high level of innovation and IT support, the changing nature of business models, the technological issues stemming from the virtual environment also pose challenges for on-site examinations and the finding of evidence; addressing these and prioritising disclosure and consumer protection considerations will be warranted in the future (Hu et al 2016).

An international comparison shows that the EBA has highlighted several tools for the supervision of online financial services, which allow the efficient measurement and management of the risks associated with P2P. These include the disclosure of the general risks inherent to P2P, the rating of creditors and borrowers, KYC (Know Your Customer) tasks, the establishment of protection for financial transaction participants in the event of P2P platform operating malfunctions, and the licensing 
or at least the registration of P2P platform operation (EBA 2015). In this paper, the EBA also emphasises the regulatory practices applied in England, France, Spain and Italy, member states which all have P2P specific regulation, adding, however, that Italy's regulations do not cover every type of P2P lending. Based on all of this, China has reacted rather late to the supervisory challenges posed by $\mathrm{P} 2 \mathrm{P}$, prioritising certain risks. Nevertheless, the application of the tools recommended by the EBA are not yet widespread in Europe, and there is no generally accepted practice for addressing these challenges.

\section{Regulatory framework and certain associated supervision policy matters}

The nature of the financial institution regulatory framework primarily creates difficulties for foreign financial institutions, but may also be an issue for the supervision of the operation abroad of Chinese financial institutions stemming from diverging regulatory cultures. The regulatory framework features four tiers: at the top are the laws passed by the National People's Congress, below this level are the regulatory policies drafted by the CBRC, the third tier consists of the CBRC's authority notices and guides. The majority of the CBRC's regulatory initiatives fall within the latter category, as specific measures are generally considered more effective than a more general, principle-based approach (He 2014). The measures adopted at this level generally address current regulatory issue and mainly define rules on the activities of financial institutions, financial products and corporate governance systems (e.g. customer rating, risk assessment, contracting procedures, exposed monitoring, etc.). The aforementioned difficulty consists of the fourth supervisory regulatory level, which combines the principle- and rule-based approach and is referred to as Window Guidance. ${ }^{7}$ The CBRC uses the associated measures to supervise the activities of financial institutions in line with regulatory objectives. This is because Window Guidance tools are generally not applied in writing (so their enforcement through legal avenues is not possible), and their objective is to inform financial institutions of the current regulatory intention or to draw attention to certain risks, but in some cases, Window Guidance was used to restrict lending to certain sectors or to define the volume thereof. Window Guidance is a kind of legacy of the planned economy, and can be objected to because its use in the context of monetary policy, for instance, could contribute to the emergence of stop-and-go cycles by intervening directly in lending (Delatte 2008), and may also trigger the same effect when used as a supervisory policy tool. The CBRC also uses this tool to support economic policy objectives: for instance in 2007, it fostered

\footnotetext{
${ }^{7}$ Window Guidance was introduced in China by the PBC in 1998, and was applied on numerous occasions, including in 2005 to boost credit supply to the rural economy and the non-public sector, and to increase credit supply following the global crisis (Barth et al. 2013).
} 
increased credit supply to pig farmers to boost the supply of pigs, as there was a shortage at the time (He 2012). Window Guidance tools offer the CBRC flexibility and the possibility for immediate action in the context of the regulation of financial institutions of wildly varying size and scope of activity. Their use replaces the need for formally supplementing and amending laws and regulatory guidelines on a frequent basis, but verbal notification carries the risk of losing or changing the gist of the message, and understanding this element of regulatory culture for the financial institutions operating in China and the authorities overseeing the Chinese financial institutions operating abroad is often difficult, as it may be synonymous with a lack of transparency.

\section{Summary}

The Chinese supervisory toolset gives the flexibility for the supervisory authority to handle the risks and challenges that may arise. However, with the spread of the shadow banking system, supervisory bodies were unable to respond with sufficient efficiency with the flexibility afforded by the applied toolset. Numerous authority notices were issued and awareness-raising measures introduced, followed by new ones, and still handling the shadow banking system remains a challenge for supervisory authorities, although this also stems from the financial institutional system's idiosyncrasies.

Handling Digital Finance and the associated risks is also a priority for supervisory bodies. In this regard, several initiatives and specific recommendations have emerged following an initially lenient supervisory approach, but supervising the area calls for the establishment of a relevant legislative environment.

Effectively addressing the challenges currently facing Chinese supervisory authorities will require a certain degree of integration of the current supervisory body, and reinforcing communication among supervisory bodies is essential. Studying the supervisory tools linked to the rise of Digital Finance is also pivotal, as managing the risks inherent to Digital Finance will also become a challenge for Hungary in the near future. 


\section{References}

Achhorner, T. - Chng, J. - Michaelis, H. - Tang, Tj. (2006): Banking on China - Successful Strategies for Foreign Entrants. The Boston Consulting Group, Boston, MA.

Delatte, A.L. (2008): Monetary Policy and Macrocontrol in China: The Actual Impact of Window Guidance. Hong Kong University of Science \& Technology, Seminar Papers.

Barth, J.R. - Li, L. - Li, T. - Song, F. (2013): Policy Issues of China's Financial Globalization. Elsevier Inc. Publications, Chapter 25., pp. 355-365.BIS (2013): Assessment of Basel III regulations - China. Regulatory Consistency Assessment Programme (RCAP). Bank for International Settlements, Basel Committee on Banking Supervision, September. http:// www.bis.org/publ/bcbs264.pdf Downloaded: 8 August 2016

Bloomberg (2016): China's Hidden Unemployment Rate. Official employment data may underestimate the real picture. http://www.bloomberg.com/news/articles/2016-06-05/ china-s-hidden-unemployment-rate Downloaded: 8 August 2016

CBRC (2016): About The CBRC. http://www.cbrc.gov.cn/showyjhjjindex.do Downloaded: 23 August 2016

Esheng, C. (1999): Financial Supervision in China: Framework, Methods and Current Issues. Policy Papers No. 7., Bank for International Settlements (BIS), pp. 169-173.

EBA (2015): Opinion of the European Banking Authority on lending-based crowdfunding. EBA Publications, 26 February, No. EBA/Op/2015/03.

https://www.eba.europa.eu/documents/10180/983359/EBA-Op-2015-03+\%28EBA+Opinion+on+lending+based+Crowdfunding\%29.pdf Downloaded: 12 October 2016

EC (2014): Commission Implementing Decision of 12 December 2014 on the equivalence of the supervisory and regulatory requirements of certain third countries and territories for the purposes of the treatment of exposures according to Regulation (EU) No 575/2013 of the European Parliament and of the Council.

http://eur-lex.europa.eu/legal-content/EN/TXT/?uri=CELEX\%3A32014D0908 Downloaded: 12 October 2016

FSB (2015): 2015 update of list of global systemically important banks (G-SIBs). FSB Publications, 3 November.

http://www.fsb.org/wp-content/uploads/2015-update-of-list-of-global-systemically-important-banks-G-SIBs.pdf Downloaded: 12 October 2016

He, W. (2012): Banking Regulation in China: what, why, and how? Journal of Financial Regulation and Compliance, Vol. 20. No. 4., pp. 367-384.

He, W. (2014): Banking Regulation in China. The Role of Public and Private Sectors. Palgrave MacMillan, New York. 
Hu, B. - Yin, Z. - Zheng, L. (eds.) (2016): Development of China's Financial Supervision and Regulation. Palgrave MacMillan, Published by Springer Nature, New York.

IMF (2016): The People's Republic of China - 2016 Article IV Consultation Press Release; Staff Report; and Statement by the Executive Director for The People's Republic of China. IMF Country Report No. 16/270, August.

https://www.imf.org/external/pubs/ft/scr/2016/cr16270.pdf Downloaded: 13 October 2016

Jingu, T. (2016): China Set to Step Up Regulation of Internet Finance from 2016. Nomura Research Institute, Ltd. (NRI) vol. 235. 10 March.

Komlóssy, L. - Kovalszky, Zs. - Körmendi, Gy. - Lang, P. - Stancsics, M. (2015): Kína: a tervgazdaságtól a modern bankrendszerig. Hitelintézeti Szemle, 14. évf., Különszám, November, pp. 134-144.

Lasak, P. (2015): Regulatory Responses to the Chinese Shadow Banking Development. Jagiellonian Journal of Management, Vol. 1. No. 4. pp. 305-317.

Law of the People's Republic of China on Commercial Banks (2003).

Linden, R.W.H. Van der (2015): China's Shadow Banking System and its Lurking Credit Crunch: Causes and Policy Options. In: E. Beccali \& F. Poli (eds.), Lending, Investments and the Financial Crisis. Palgrave MacMillan, New York, pp. 305-317.

Loechel, H. - Packham, N. - Xiang Li, H. (2010): International Banking Regulation and Supervision after the Crisis (Implications for China). EU-China Business Management Training Project, Working Paper Series, No. 013.

MNB (2013): Vitaanyag az MNB pénzügyi felügyeleti funkcióinak megerősitéséről (Working document on the reinforcement of the MNB's financial supervisory functions) Published: http://www.mnb.hu/letoltes/felugyelet-hu.pdf Downloaded: 22 July 2016

PBC (2016): About PBC. http://www.pbc.gov.cn/english/130712/index.html Downloaded: 23 August 2016

PWC (2010): Foreign banks in China. Price Waterhouse Coopers, May. https://www.pwc.com/ th/en/publications/assets/pdf-foreign-banks-in-china2010.pdf Downloaded: 8 August 2016

SEACEN (2013): The South East Asian Central Banks (SEACEN) Research and Training Centre Publications: People's Bank of China, pp. 15-20. http://www.seacen.org/GUI/pdf/publications/bankwatch/2013/3-PBC.pdf Downloaded: 29 August 2016

Seregdi, L. (2016): De mit kezdhetnek a bankok az árnyékbankokkal? (But what can banks do with shadow banks?) MNB Publications 27 July https://www.mnb.hu/letoltes/seregdi-laszlo-de-mit-kezdhetnek-a-bankok-az-arnyekbankokkal.pdf Downloaded: 7 October 2016 
Zhang, H. (2015): Asia Viewpoint: China Bids Farewell to the Loan-to-Deposit Ratio Cap. What impact will an amendment to a decades-old banking law have on liquidity risk and the overall banking industry in China? Global Association of Risk Professionals (GARP) Publications, October 9. http://www.garp.org/\#!/risk-intelligence/detail/a1Z40000000HwFxEAK Downloaded: 30 August 2016

Zheng, L. (2015): The Shadow Banking System of China and International Regulatory Cooperation. Centre for International Governance Innovation (CIGI), Paper No. 6. March.

Zhou, W. - Arner, D.W. - Buckley, R.P. (2015): Regulation of Digital Financial Services in China: Last Mover or First Mover? Tsinghua China Law Review, Vol. 8:25, pp. 25-61. 